\title{
Liver damage in HIV+HBV co-infected patients determined by transient elastography
}

\author{
Elena Dumea ${ }^{1,2^{*}}$, Adrian Streinu-Cercel ${ }^{3}$, Sorin Rugină ${ }^{1,2}$, Lucian Cristian Petcu ${ }^{1}, Z_{i z i}$ Niculescu' \\ Alina Doina Nicoară ${ }^{1}$, Simona Claudia Cambrea ${ }^{1,2}$ \\ From The 7th Romanian National HIV/AIDS Congress and The 2nd Central European HIV Forum \\ Sibiu, Romania. 29-31 May 2014
}

In our country the prevalence of HIV-HBV co-infection in young infected patients, between 1985-1990, transmitted through nosocomial or vertical path is approximately $40 \%$.

We followed the prevalence and risk factors associated with liver damage in HIV+HBV infected patients. Longitudinal evaluation of liver fibrosis was carried out in the patients included in the study group, by transient elastography (TE). Several studies using non-invasive methods for the assessment of fibrosis have been performed in HIV infected patients, and in patients co-infected with hepatitis virus $B$, although up to now these methods have not been validated for this segment of the population. For statistical analysis, the TE results were designated to different stages of fibrosis in accordance with the previous recommendations. The predefined cut-off values were: F0-F1 $\leq 7.1 \mathrm{kPa}, \mathrm{F} 2-\mathrm{F} 3>7.1$ and $\leq 12.5 \mathrm{kPa}$ and for cirrhosis (corresponding to $\mathrm{F} 4$ ) $>12.5 \mathrm{kPa}$.

We included in the study 71 patients co-infected with HIV and hepatitis B. $71.85 \%$ of patients had minimal liver damage, $18.30 \%$ of them had moderate to severe fibrosis, 9.85\% were F4. Patients were divided according to CD4 count into three groups: CD4 (0-200)/cmm, [200-500)/ $\mathrm{cmm}$, and $>500$ cells $/ \mathrm{cmm}$. By applying the ANOVA test we found significant differences between the 3 groups $(\mathrm{p}=0.037<\alpha=0.05, \mathrm{~F}=3.472)$ and reading the Bonferroni table shows that there are significant differences between the values of FibroScan only in patients coinfected with $\mathrm{HIV}+\mathrm{HBV}$ with CD4 appropriate intervals $(0-200]$ and $(>500)$ [cells $/ \mathrm{cmm}], \mathrm{p}=0.033<\alpha=0.05$, confidence interval (CI) $95 \%(0139,4572)$. We didn't find significant differences regarding patients' liver disease between groups with HIV-RNA viral load $<400$ copies/mL compared to those with levels $>400$ copies $/ \mathrm{mL}$. For assessing the role of

Ovidius University, Constanța, Romania

Full list of author information is available at the end of the article hepatitis virus B in liver disease severity in co-infected patients, patients were divided into two groups: HBVDNA level $\leq 2,000 \mathrm{IU} / \mathrm{mL}$ and $>2,000 \mathrm{IU} / \mathrm{mL}$. Since $\mathrm{p}=0.006<\alpha=0.05$, there are significant differences between the mean values of FibroScan in the two groups, HIV $+\mathrm{HBV}$ patients with HBV-DNA $(0-2,000 \mathrm{IU} / \mathrm{mL}$ and $>2,000 \mathrm{IU} / \mathrm{mL}), 95 \% \mathrm{CI}(-4.642,-0.788)$.

We confirm the role of HIV-induced immunosuppression in liver disease progression. As well we confirm the presence of more severe liver disease linked to hepatitis virus $\mathrm{B}$ replication.

\section{Authors' details}

${ }^{1}$ Ovidius University, Constanța, Romania. ${ }^{2}$ Clinical Hospital of Infectious Diseases, Constanța, Romania. ${ }^{3}$ Carol Davila University of Medicine and Pharmacy, Bucharest, Romania.

Published: 29 May 2014

doi:10.1186/1471-2334-14-S4-P18

Cite this article as: Dumea et al.: Liver damage in HIV+HBV co-infected patients determined by transient elastography. BMC Infectious Diseases 2014 14(Suppl 4):P18.

Submit your next manuscript to BioMed Central and take full advantage of:

- Convenient online submission

- Thorough peer review

- No space constraints or color figure charges

- Immediate publication on acceptance

- Inclusion in PubMed, CAS, Scopus and Google Scholar

- Research which is freely available for redistribution 